\title{
Recent Developments in the Credit Card Market and the Financial Obligations Ratio
}

\section{Kathleen W. Johnson, of the Board's Division of Research and Statistics, prepared this article. Tsz-Yan Doris Sum provided research assistance.}

Over the past fifteen years, U.S. households in the aggregate have devoted an increasing share of their after-tax income to the payment of financial obligations. Much of the increase is attributable to a rise in the level of credit card debt, which has raised the share of households' aggregate after-tax income that is devoted to credit card payments. In turn, the rising share of credit card debt in overall financial obligations may stem from several notable changes in the credit card market over this period.

Financial obligations such as credit card debt and housing costs require monthly payments whose level relative to income is, of course, a vital concern to the individual household. A household's choice to take on obligations that increase these payments may represent an accurate assessment by the household of its ability to make payments on its obligations. However, devoting more income to required debt payments and other obligations will make the household more likely to default in the event of job loss or illness.

Likewise, an aggregate measure of payments on household financial obligations relative to income is of interest to economic policy makers because of potential concerns about the vulnerability of the household sector as a whole. In 1980, the Federal Reserve Board began calculating and tracking the ratio of households' aggregate required monthly payments on mortgage and consumer debt to their aggregate after-tax (that is, disposable) income, a measure called the debt service ratio (DSR). To gain a broader picture of households' financial position, the Federal Reserve Board in 2003 introduced a new measure, called the financial obligations ratio (FOR). ${ }^{1}$ The new measure added other types of obligations to those of the DSR, namely payments on auto leases and housing expenses for rent, homeowner's insurance, and real estate taxes. As with the DSR, the obligations in

1. For a discussion of the TSSR and FOR, see Tynan, Tohnson, and Pence $(2003)$.
1. Household financial obligations ratio (FOR), 1980-2005:Q2

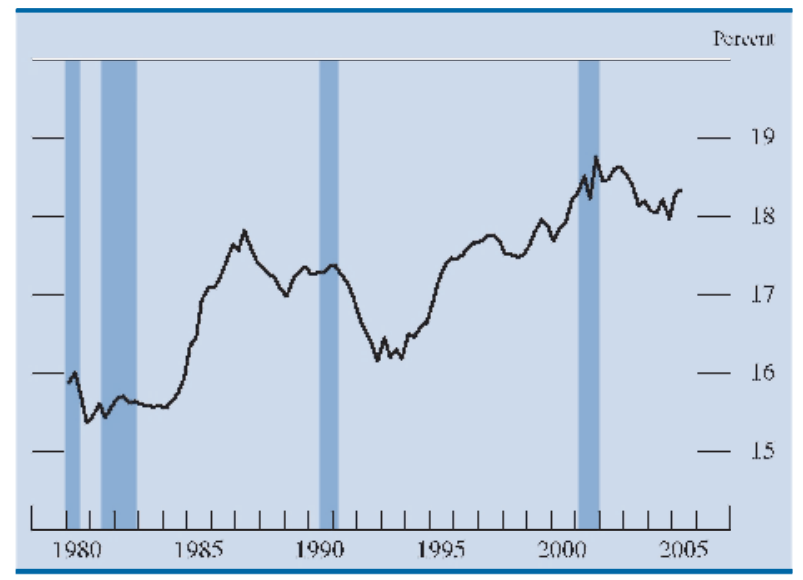

NOTE: The data are quarterly. Shaded bars are periods of recession as defined by the National Bureau of Economic Research. The FOR consists of the aggregate required monthly payments of the household sector on consumer debt, mortgages, homeowner's insurance, real estate taxes, rent, and auto leases as a percent of aggregate after-tax personal income.

SOURCE: Federal Reserve Board (www.federalreserve.gov/releases/ housedebt).

the FOR are presented as a share of aggregate, aftertax income.

For a given level of aggregate income, no clear line separates an appropriate level of payments on financial obligations from an excessive one, but the current level of the FOR is elevated relative to historical experience. It stood at $181 / 3$ percent in the second quarter of 2005, a level noticeably above its value fifteen years earlier (chart 1). Of the major components of the FOR, the ratio of credit card payments to disposable income rose the most over this period. Mortgage payments also rose significantly as a share of income, but payments on other types of debt obligations fell (chart 2).

This article argues that three important developments in the credit card market over the past fifteen years account for most of the rise in credit card payments relative to income. First, improvements in credit-scoring technology and the advent of riskbased pricing of credit card debt have increased the share of households - particularly lower-income households-with a credit card. Second, in the 1990s, credit card interest rates began to vary with changes 
2. Selected components of the financial obligations ratio, 1989-2005:Q2

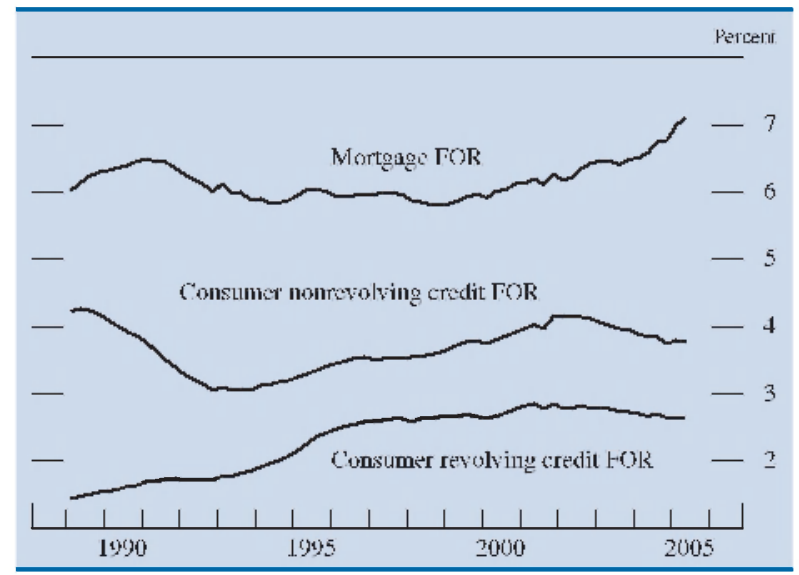

NOTE: The data are quarterly. For a description of consumer revolving credit, see text note 2 . Vonrovolvins debt consists of credit accounts that terminate when the balances are paid off; such accounts include loans for motor vehicles, household goods, and education. Data shown for each type of debt are the aggregate required monthly payments for that type as a percent of aggregate after-tax income. See also note to chart 1.

SOURCE: Federal Reserve Board

in broader market interest rates. In turn, this co-movement led to an especially pronounced decline in credit card interest rates when, beginning in 2001, market rates turned sharply lower; the decline in credit card rates raised the demand for credit card debt. Finally, households have increased their use of credit cards as a convenient means of paying for daily purchases.

The article estimates the quantitative effect of each of these three developments on the revolving consumer (that is, nommorlgage) credit portion of the FOR - the ratio of required minimum payments on revolving consumer credit relative to disposable income. ${ }^{2}$ The analysis indicates that these three developments in the credit card market together accounted for most of the rise of the revolving credit FOR and played a strong role in the rise of the total FOR.

In a concluding section, the article considers these findings in relation to the possible economic implications of the rise in the revolving credit FOR. For example, a rise in required credit card payments stemming from a greater use of credit cards to pay for day-to-day purchases may not signal greater finan-

2. A credit cart account is at lype of comsumer (that is, nonmortgago) rovolving crodit. Gencally, rwolving credit cxtensions can be made at the customer's cliscretion, providet that they do not cause the oulstanting batance of the account to exceed a preaminget credit limit. Rovolving credit repayments are also at the customers discretion. subject to a prearranged minimum, and may be mads: in ont: or more installments. More than 90 percent of consumer revolving deht is credit carcl debt. cial vulnerability if households are willing and able to pay off these card charges each month. In addition, the rise in payments associated with the increase in credit availability due to credit scoring may be accompanied by some benefits: More widespread access to credit may help more households maintain their consumption during temporary income disruptions and in turn contribute to the stability of the macrocconomy.

\section{DEVELOPMENTS IN THE CREDIT CARD MARKET.}

Three developments in the credit card market likely accounted for much of the rise in household financial obligations over the past fifteen years: an expansion in the prevalence of credit cards among lower-income households, the widespread adoption of variable-rate cards, and a greater willingness of households to use their credit cards for day-to-day purchases of goods and services. The available data-from the Federal Reserve Board's triennial Survey of Consumer Finances - allow a comprehensive analysis of the importance of each development for the period. The survey conducted nearest the beginning of the fifteenyear period was in 1989, and the survey for which the most recent data are available was conducted in 2001.

\section{The Expansion of the Credit Card Market}

More and more households have gained access to credit cards over the past decade and a half. The share of households with at least one credit card rose from 70 percent in 1989 to 76 percent in 2001 (table 1). Determining which group of cardholders in 2001 would not have been cardholders in 1989 will help us estimate the effect that the expansion in cardholding had on household financial obligations. Broadly speaking, an expansion of ardholdins could arise through two channels. First, changes in supply or demand conditions in the credit card market, holding the characteristics of households fixed, could increase the share of households with credit cards. Such developments may include changes in credit card underwriting standards or a general increase in households' desire for credit cards. Second, changes in household characteristics may increase the percentage of households who qualify for a credit card under a given set of underwriting standards.

The analysis presented below suggests that much if not most of the rise in ardholdins over the 19892001 period came from an expansion of supply to riskier households - those that would not have quali- 
1. Proportion of households with at least one credit card, by income quintile, selected years, 1989-2001 Percent

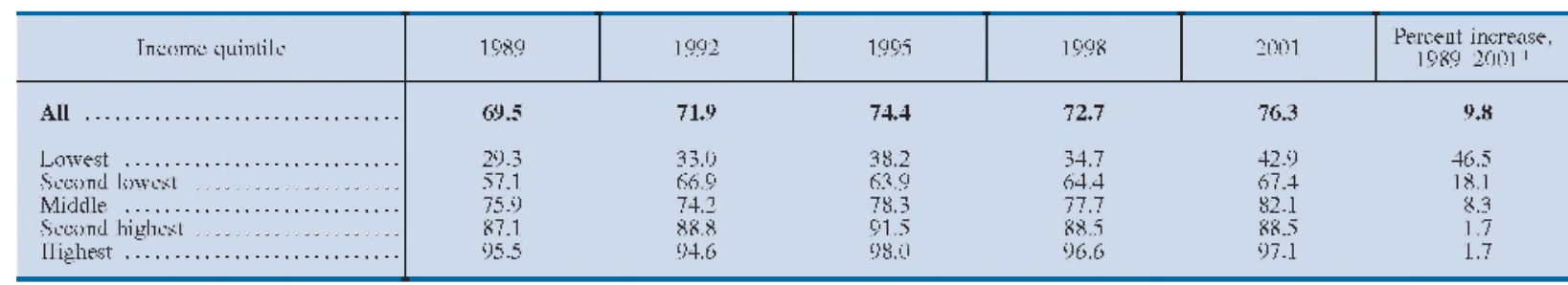

NoTE: For types of credit cards considered and definition of concepts of household and head of household used in the tables, see text note 3 .

1. Computed trom unrounded data.

fied for a card in 1989. In the mid-1990s, card issuers began ranking applicants according to their probability of default; instead of denying cards to all those who posed too great a risk for a given interest rate on the card, they began issuing cards to some of the higher-risk applicants and set the interest rate on these riskier accounts high enough to compensate the lenders for the greater risk (Edelberg, 2003). The practice of issuing cards to higher-risk household was a significant change in the supply conditions in the credit card market.

\section{Credit Scoring and Risk-Based Pricing}

Lenders can rank applicants according to their likelihood of default through a measure called a credit score, which aggregates the factors in a potential borrower's credit history that are associated with a willingness and ability to pay. The higher the credit score, the more likely is the applicant to pay as agreed on a new credit account. The adoption of flexible, or risk-based, pricing allows creditors to issue cards to less-qualified applicants in exchange for a higher interest rate on the card. Credit scoring was considered by providers of consumer credit as early as the late 1930s, but the practice did not become widespread until the 1990 s, when computers capable of processing large amounts of data became widely used (McCorkell, 2002).

Risk-based pricing has increased the availability of credit cards for all households, but its effect has been the greatest among riskier households. In particular, the rate of cardholding among households in the lowest quintile of the income distribution rose about half, from 29 percent to 43 percent, between 1989 and 2001 (table 1), whereas the rate of ardlolding rose only 10 percent in the general population, from 70 percent to 76 percent. Among households in the lowest income decile (not shown in the table), the rate of sardholdins about doubled over the period, from 18 percent to 35 percent. The rate among house-
SOURCE: Here and in the following tables, Federal Reserve Board's Survey of Consumer Finances and author's calculations.

holds who reported having been previously denied credit also rose more than did the overall rate.

These patterns are consistent with an expansion of ardholdins through the first channel-in this case, a higher supply of cards through the use of credit scoring. The possibility remains, however, that the increase in cardholdin may have also arisen, at least in part, through the second channel-that is, the characteristics of these new cardholders may have improved over the period. For example, they may have demonstrated a better employment history or a better record of paying rent and utility bills; in this case, a rise in creditworthiness could have produced more widespread sardholdins among lower-income households rather than a change in underwriting standards. We can sort out the relative influence of the two channels with a statistical model.

\section{Who Are the New Cardholders?}

I apply a statistical model to data from the Federal Reserve Board's triennial Survey of Consumer Finances (SCF). Each SCF obtains detailed demographic and financial information from a statistically representative national sample of approximately 3,000 households. The model used here links the characteristics of households in the survey to the probability that they hold at least one credit card.

The characteristics used to predict zardholding were income, wealth, number of children, the age of the household head, and indicators for the sex, marital status, and education of the household head. ${ }^{3}$ The predictors also included an indicator for whether a

3. See Aizcorbe, Kennickell, and Moore (2003) for a presentation of results of the 2001 SCF (the most recent survey for which data are available); see p. 30 of that work for a definition of the terms household and head of household used here. The types of cards considered in the surveys include bank-issued cards, store cards and charge accounts, gasoline company cards, and so-called travel and entertainment cards such as American Express and Diners' Club (p. 24, note 27). 
2. Selected characteristics of households, by whether they hold a credit card, 1989

Percent except as noted

\begin{tabular}{|c|c|c|}
\hline \multirow[b]{2}{*}{ Characteristic } & \multicolumn{2}{|c|}{ Mean } \\
\hline & $\begin{array}{l}\text { Holdis a } \\
\text { credit card }\end{array}$ & $\begin{array}{l}\text { Does not } \\
\text { hosld a } \\
\text { credit cand }\end{array}$ \\
\hline Thesme (Lhisusands al disllars) & 63.2 & 200 \\
\hline Wealth thousands of dollansi. & $315 \%$ & 610.4 \\
\hline Numlare of childrem & .7 & 8 \\
\hline Receutly deliuquent ${ }^{\prime}$ & 3.3 & 10.0 \\
\hline \multicolumn{3}{|l|}{ Head al hisutwithold } \\
\hline Age iyearsi .... & 48.4 & 46.9 \\
\hline tio high sthool devree. & 15.7 & 44.4 \\
\hline College dista. & 36.5 & 8.1 \\
\hline Married ........ & 64.0 & 35.0 \\
\hline Mialio. & 77.3 & 502 \\
\hline
\end{tabular}

1. Delinquent sisty days or more in the past year.

household was two months or more behind in debt payments in the past year (table 2).

These characteristics differ significantly between those households with credit cards and those without and thus serve as good predictors of cardholding. For example, in the $1989 \mathrm{SCF}$, households that held credit cards had significantly higher wealth and income than non-cardholders (table 2, first and second columns). In addition, the heads of cardholding households were more often college-educated, married, or male. Finally, cardholding households were less likely to have been behind on a loan payment in the preceding year.

The statistical model can focus on the effect that each characteristic has on the probability of cardholding by keeping the other characteristics constant. ${ }^{4}$ Estimates suggest that all the selected characteristics except the age and marital status of the household head had a large and statistically significant influence on the probability that a household held a credit card in 1989.

The model can also shed light on the extent to which changes in supply factors (lenders' willingness to issue a card to a given household) and demand factors (a given household's interest in holding one) together contributed to the rise in ardholding between 1989 and 2001.5 Any portion of the rise in credit card availability not attributable to supply and demand factors may be attributable to changes in the

4. This technique, called a probit model, has been used by Klee (2004) and Luca and Whitesell (1995), the motel doss a fairly accurate job of predicling whether each household in the 1989 data set held a credit carcl. Tt cortecly predicts actual cardholding for 91 percont of houstholds with at loast one card and 56 percent of houscholds with no card. for an owerall correst pratiction rate of 81 peront,

5. The moclet cannot identify supply factors separately from demand factors. financial characteristics that have increased the creditworthiness of households.

To separate these effects, I estimated the model first with data from the 1989 SCF and then with data from the $2001 \mathrm{SCF}$. Using the two sets of estimates and the characteristics of households in the two years, I first calculated the overall change in the estimated probability of ardholdin s between 1989 and 2001 (table 3, first column). To isolate the effect of changes in supply and demand conditions between these years, I calculated a hypothetical probability of cardholding in 2001 based on the 1989 household characteristics and the 2001 estimation results. In other words, I predicted which households in 2001 would have been holding cards if there had been no changes in the characteristics of households since 1989. The difference between this hypothetical probability for 2001 and the estimated probability for 1989 corresponds to the effect of changes in supply and demand conditions from 1989 to 2001 (table 3, second column). The part of the overall change in the estimated probability not explained by changes in supply and demand is that associated with changes in household characteristics (table 3, third column).

For the general population, the results imply that changes in supply and demand conditions account for only 2 percentage points of a 7 percentage point overall rise in the estimated probability of sardholding. But, in the lowest quintile of income, where the estimated probability of uardholding rose far more than the average, more than half of the effect -9 of the 16 percentage points of gain in the probability-is attributable to supply and demand factors. Although the model cannot distinguish changes in supply from changes in demand, the result is certainly consistent with an increase in the supply of credit cards for the lowest-income households (see also Bostic, 2002).

3. Change in the estimated probability that a household holds a credit card, and source of change, by income quintile, selected years, 1989-2001

Percent except as noted

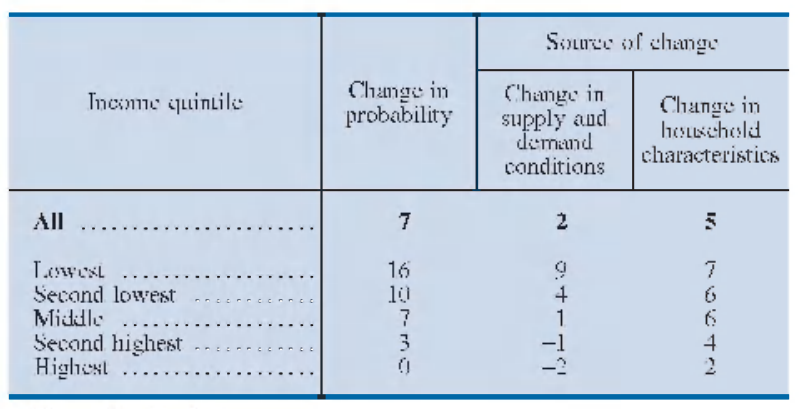

NotE: For details, see text 
The model can also be used to identify the likely households in each survey who acquired cards most recently. Such households are termed here as "new cardholders" and are defined as those households with the lowest estimated probability of holding a credit card. An examination of changes in the characteristics of new cardholders over time also suggests an increase in the supply of credit cards to riskier households (table 4). New cardholders in surveys after 1989 are more likely to have been delinquent on a loan in the preceding six months and are also younger and have more children; these patterns suggest that new cardholders now are likely less creditworthy than those in the past. Work by other researchers, who examined the $1989-95$ period, corroborates the view that the average cardholder has become riskier over that period - the average cardholder had less job seniority, had lower income, had lower liquid assets, was more willing to use debt to finance consumption (an attitude considered to be a "riskier" view of credit), and was more likely to be single and be a renter (Black and Morgan, 1998).

The credit card debt taken on by these new cardholders probably raises the ratio of aggregate measured revolving credit payments to aggregate income. The effect on the overall FOR may be damped, however, if these households substituted credit card debt for other measured forms of credit, such as personal loans and installment loans. But given that access to these forms of credit for these new cardholders was likely limited in the past, substitution (to the degree it occurred) was probably out of

4. Financial and demographic characteristics of existing and new cardholders, selected years, 1992-2001

Percent except as noted

\begin{tabular}{|c|c|c|c|c|}
\hline Cardholder and chariaturistic & 1902 & 1905 & 1998 & 201 \\
\hline 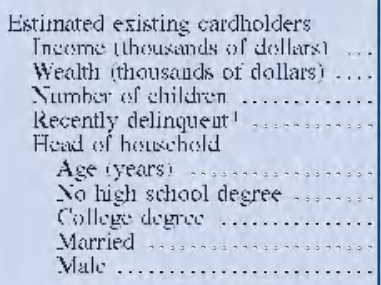 & $\begin{array}{r}56.8 \\
288.5 \\
7 \\
3.0 \\
48.7 \\
10.0 \\
42.0 \\
64.0 \\
78.0\end{array}$ & $\begin{array}{r}61.4 \\
318.9 \\
.7 \\
3.0 \\
48.7 \\
90 \\
40.0 \\
60.01 \\
780\end{array}$ & $\begin{array}{r}60.7 \\
394.4 \\
7 \\
4.0 \\
40.3 \\
7.01 \\
44.0 \\
62.0 \\
78.0\end{array}$ & $\begin{array}{r}85.3 \\
532.7 \\
7 . \\
2.0 \\
49.7 \\
6.0 \\
45.0 \\
69.0 \\
79.0\end{array}$ \\
\hline 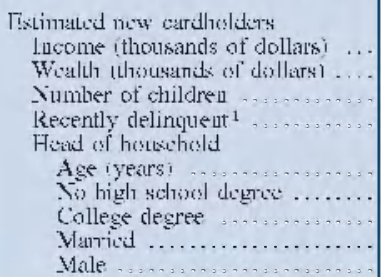 & $\begin{array}{r}8.6 \\
21.0 \\
.7 \\
9.0 \\
50.8 \\
54.10 \\
.3 \\
10.0 \\
63.0\end{array}$ & $\begin{array}{r}11.4 \\
24.2 \\
.7 \\
13.01 \\
53.1 \\
53.0 \\
5.01 \\
240 \\
54.0\end{array}$ & $\begin{array}{r}12.5 \\
7.7 \\
1.2 \\
24.1 \\
44.6 \\
51.01 \\
610 \\
1601 \\
60.01\end{array}$ & $\begin{array}{r}16.0 \\
24.2 \\
1.0 \\
1.9 .0 \\
46.1 \\
4.10 \\
3.0 \\
21.0 \\
61.0\end{array}$ \\
\hline
\end{tabular}

NoTE: For calculation of existing and new cardholders, see text.

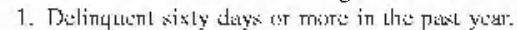

unmeasured forms of debt. For example, in a survey of households in low- and moderate-income areas of Los Angeles, Chicago, and Washington, 53 percent of respondents said they would rely on friends or family to borrow $\$ 500$ for three months, and 15 percent said they had obtained financing from institutions not captured by aggregate statistics, such as pawn shops, payday lenders, and rent-to-own establishments. ${ }^{6}$

\section{Closer Relation of Credit Card Interest Rates to Broader Market Rates}

The second important development in the credit card market is the closer relation of credit card interest rates to broader market rates. In particular, this development allowed credit card interest rates to move down when market rates began to fall in 2001, which in turn significantly boosted the demand for credit card debt and the payments required to service this debt.

One might expect credit card interest rates to vary with the cost of funds, given the important role of these costs in lenders' credit card expenses. ${ }^{7}$ But, in the 1980 s and early $1990 \mathrm{~s}$, credit card interest rates changed little, showing a correlation with the prime rate (a good measure of the cost of funds) of only about 0.09 (see box "Theories of Credit Card Interest Rate 'Stickiness" " for a discussion of some possible reasons for this early unresponsiveness). The correlation subsequently rose sharply, and it has averaged 0.90 during the past ten years. Notably, the average credit card interest rate in real terms (that is, adjusted for inflation) declined in tandem with the real prime rate from the first quarter of 2001 to the second quarter of 2004, when the real prime rate hit its most recent low (chart 3 ).

The rapid growth of variable-rate cards since 1989 materially contributed to the increase in the flexibility in interest rates on credit cards. A variable-rate credit card carries an interest rate that maintains a constant margin, or spread, over a stated market reference rate such as the prime rate or the LIBOR (the London interbank offered rate). In 1989, variable-rate credit cards accounted for only about 3 percent of credit card accounts. By 1994, this share had grown

6. Siedman, Hababou, and Kramer (2005). Rent-to-own establishments offer comsumers the option to acculuire the ownership of merchandise by menting it for a spocitiod poriod of time.

7. One industry soura found that the cost of funds accounted for 43 percent of the cost of credil extendect through credil cards betwen 1990 and 1993 (Credil Card News, May issue of various years). 
3. Average real credit card interest rate and the real prime rate, 1989-2005:Q2

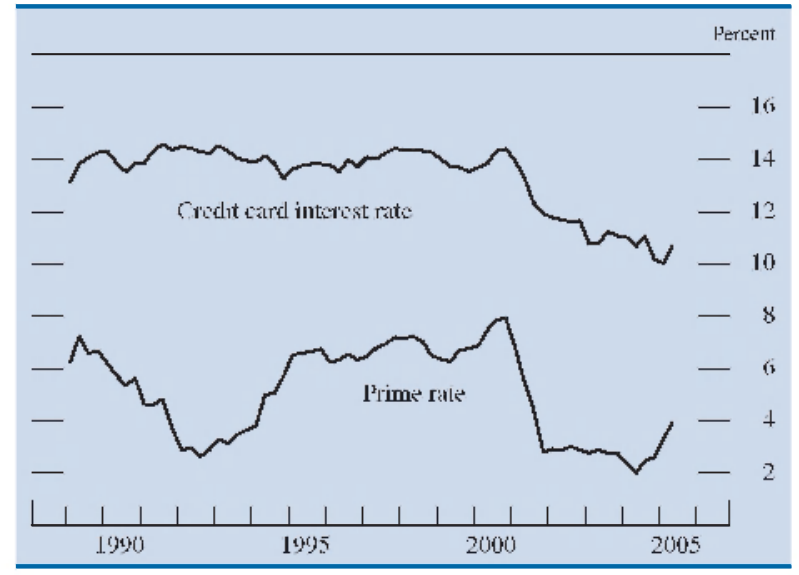

NoTE: The data are quarterly.

SOURCE: Federal Reserve Board

to about 60 percent; it is now probably close to 75 percent. $^{8}$

A key to the lender's choice of variable-rate versus fixed-rate pricing lies in the behavior of cardholders who are the most profitable to card issuers. ${ }^{9}$ In general, the most profitable cardholders are those who carry large amounts of debt on their cards because they pay more interest than other cardholders (although this benefit is offset by the fact that some high-debt cardholders may have a higher likelihood of default). Several factors have increased the odds that profitable cardholders will switch to lower-rate cards; these factors have thus increased the incentive for lenders to lower credit card interest rates when their cost of funds allows it.

The first of these factors is that households may have become better able to predict how much credit card debt they will carry from month to month in the future and how much in interest costs they will incur. According to recent research, most consumers who were presented with a choice between two credit card contracts chose the contract that was optimal given their actual future borrowing. ${ }^{10}$ This realistic assessment by cardholders of their borrowing needs implies that a large proportion of borrowers who carry debt will respond to an offer of a card with a lower rate.

8. Stango $(2000)$ and author's calculations.

9. The greater provalsene of variable-rate cards can also be explained by an incosease in market concentration (see Stando, 2000), ancl, incleet, the ten largest card issuers doubled their markel share trom 40 peresnt in 1989 to about 80 pcront in 2004.

10. Ngar'wal and others (2005); the data in that work cannot demonstrate a change from the early to late 1990s in households ability to assess their bonowing needs
A second reason that consumers with relatively large amounts of credit card debt may be more responsive to changes in credit card interest rates is that the cost of searching for a lower-rate card has declined. For example, a dramatic increase in advertising by credit card companies may have made it easier to compare rates across cards. The number of credit card solicitations jumped from about ten per U.S. household in 1992 to more than forty in 2004. ${ }^{11}$ In addition, the Internet has become a potent source of information about credit card terms; a recent online search of the term "compare credit card interest rates" yielded about 1,000 results. Changes in federal law have probably also made it easier for households to compare credit card terms. In 1988, the Congress amended the Truth in Lending Act to require that all credit card solicitations include information about the annual percentage rate, annual fee, minimum finance charge, transaction charge, grace period, balance computation method, cash advance fee, late payment fee, over-the-limit fee, and balance transfer fee. ${ }^{12}$

Lastly, credit card lenders have invested in information technology that allows them to better identify the least risky households with high levels of credit card debt. As a result, lenders can make offers to only those high-debt consumers who are expected to be profitable. Thus, although consumers with high levels of credit card debt are more likely than others to be turned down for a credit card, the gap in probabilities is narrowing, ${ }^{13}$ All told, these developments have likely increased the share of switching done by profitable households with high levels of credit card debt and in turn increased the incentive for lenders to adjust credit card interest rates.

\section{Credit Cards as a Payment Method}

A third important development in the credit card market is an increase in the transactions demand for credit cards. Such demand harks back to the purpose

11. http/coresynowate,com/mailwolasp: and www census.gow/ population/www/index.html (under "Population Lata by Subject" select "Families" and then sctoll to "Table HH-1").

12. Liven with a decline in scarch costs. credit card intersat rates may remain sticky it protitable. high-debt consumers remain less likely to search than other households. Analyses of SCF datat by Calem and Mester (1995) do show a negative relationship betwen high cradit card debt and willingens to shop for botter credit card Lemo: however, work by Calem. Gordy, and Mester (2005), Crook (2002), and the present author indicate that the relationship has wakened since then.

13. This assortion is basted on an analysis of 1989 and 2001 SCI ${ }^{i}$ data by the present author that builds on work by Calem and Mester (19) 95$)$. 


\section{Theories of Credit Card Interest Rate "Stickiness"}

Credit card interest rates did not respond to changes in the cost of funds before the mid-1990s. The causes of this interest rate "stickiness" have been debated in the economics literature. Many authors have asserted that when the cost of funds declined, credit card lenders did not reduce their interest rates because doing so seemed likely to attract borrowers who were less profitable.

One theory posited the existence of three types of credit card consumer to explain why only less profitable consumers were likely to switch to cards with lower interest rates (Ausubel, 1991). The first type used a credit card only to transact (make day-day-purchases) and did not carry a balance. The second type used a card to borrow and planned to carry a balance. The third type did not plan on borrowing for the long term but ultimately was likely to carry a balance. The first and third types would not switch cards when a lower interest rate alternative was presented because they did not think they would borrow and pay interest; only consumers who knew they would borrow would decide to switch. If those who planned to carry a balance are less profitable than other consumers (perhaps because they have higher default rates) firms would be reluctant to reduce their interest rates.

Another theory explained sticky interest rates by asserting that the most profitable customers had higher costs both

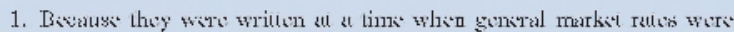
dewlining. these papers di) not address the causes of upward stickiness, that is, the reasous why credit card interest rates did not rise with general market rates. of searching for a new card and of switching to that card (Calem and Mester, 1995). In this argument, consumers with high amounts of debt were the most profitable for the credit card lenders. ${ }^{2}$ But these consumers were also the least likely to search for a card with a lower interest rate because they were more impatient (which is why they borrowed so much) and because they were more likely to be turned down for a new card owing to their high debt. All told, these factors implied that a firm that lowered its rates would have its pool of borrowers shift toward less profitable ones (those with less debt) because they were the most likely to switch to a lower-rate card.

A third theory asserted that credit card interest rates appeared sticky because borrowers switched from credit cards to other forms of financing when the cost of funds declined (Brito and Hartley, 1995). In response to the loss of borrowers, credit card lenders lent to riskier households and charged them higher interest rates to compensate for their higher probability of default. This change in the composition of credit card borrowers offset the effect of a lower cost of funds; thus, credit card interest rates did not decline with the cost of funds.

2. Lhis assertion is plausible: According to Credit Card News May issue, various yearsi interest charges on horrowing accounted tor all average of

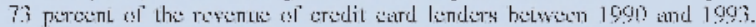
llowever, some portion of the protits from interest charges levied on high-

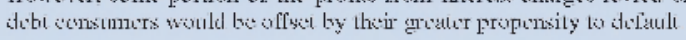

of the original third-party charge card, which was issued in 1950 by Diners' Club for use in restaurants (Evans and Schmalensee, 2005, p. 4). Charges had to paid in full each month, so the card represented only a convenient payment method rather than a way to obtain longer-term financing. American Express cards were launched in 1958, also as transaction cards, but Bank of America followed in the same year with the first general-purpose credit card on which only a portion of the balance needed to be paid each month.

Over time, many financial institutions began offering cards that offered the option of paying only a portion of the balance each month. Although the long-term-loan component of credit card debt came to exceed the transactions component, the transactions demand for credit cards has nonetheless continued to grow. For transactions, credit cards have several advantages over cash. First, unlike cash, a credit card may offer consumers protection when it is lost or stolen. Second, credit cards permit households to earn interest on their funds during the period between the transaction and the payment of the credit card bill (the interest earned in this way is known as "float"). Indeed, researchers have found that households with credit cards tend to have lower balances in their transactions accounts than do households without credit cards, which suggests that households may be holding funds in accounts that offer higher yields until they need to pay off their credit cards. ${ }^{1+}$ Credit cards also offer the consumer an advantage over checks in that it is faster to swipe a card through a terminal than to write a check.

In more recent years, transactions demand for credit cards has been spurred by card issuers that have responded to increasingly intense competition by offering rewards for heavy credit card use. Such rewards include cash-back rebates on purchases, discounts on merchandise, and "mileage" programs that cover travel expenses. These programs, which add to

14. Son, for cxample. Duca and Whitssoll (1995). Whits (1976), and Mandell (1972). Transactions accounts are checking, savings, ancl money market accounts as well as cash accounls at brokerayes. 
the benefits of using cards over cash, encourage the transactions use of cards because they generally do not require the cardholder to carry the balance from month to month to receive the rewards. ${ }^{15}$

Transactions demand has also grown because opportunities for credit card transactions have risen in the past decade. ${ }^{16}$ According to the Census Bureau, sales over the Internet and by mail order have increased considerably in recent years, and credit cards likely are used for many of these transactions. Sales in these categories have increased close to 15 percent per year since 1999, the first year for which e-commerce data were collected ${ }^{17}$ Even traditional brick-and-mortar stores have increased their acceptance of credit cards. In 1989 , about 23/4 million merchants accepted Visa cards; by 2000 , that number had reached $4 \frac{1}{4} 4$ million. ${ }^{1 s}$

Increased transactions demand raises the aggregate level of credit card debt outstanding as currently measured. Suppose, for example, that a consumer charges $\$ 500$ on the fifteenth day of one month and pays it off on the fifteenth day of the next month. Aggregate credit is measured as the stock of debt at the end of each month, so the measured estimates will capture the $\$ 500$ owed at the end of the month in which the charge was made. Thus, measured aggregate credit includes debt that will be paid off in the next month (transactions demand) as well as debt that will be paid off over a longer period. If transactions demand rises more rapidly than the demand for longer-term debt, then measured aggregate debt will also grow faster than the demand for debt.

According to recent research, transactions demand as a share of measured revolving debt rose from about 6 percent in 1992 to 11 percent in 2001 (Johnson, 2004). That analysis also suggests that the growth in transactions demand was particularly rapid in the latter part of the 1990s. Had transactions demand remained constant from 1992 to 2001, the

15. Card issuers can bontit trom an increase in transactions demand because they mecive teveute from the ters they levy on the merchant for each transaction.

16. However the increase in these opporlunilies has also enabled the growth of a substitute for the transaction demand for credit cards-the use of debit cards. Zinman (2005) prowides widence that households that camnot take at vamlage of foat hecause they cany a balanes on their cradit cards tond to use dobit cards. Klec (2004) identitis seweral factors that may have led to an increast in debit card use, perhaps at the expense of credil carts.

17. The Cemsus Bureau delines e-commerce sales ats "sates of goods and services whom an order is placed by the buyser or price and terms of sale are negoliated over an TnLemet, extranet, Flectronic J Jata Interchange (FID) network, electromic matil, or other online system. Payment may or may not bo online" (U.S, Lepartment of Commerse, 2005),

78. www.usavisat.com/aboul_visa/newsroom/statistics/ acedplance.himi growth of measured credit card debt during that period would have been slower by about 1 percentage point per year, and the level of credit card debt in 2001 would have been $7 \frac{1}{2}$ percent lower than it actually was. These results are roughly consistent with data suggesting that transactions demand accounted for about 10 percent of measured credit card debt over the past decade and a half 19

\section{DEVELOPMENTS IN THE CREDIT CARD MARKET. AND THE REVOLVING CREDIT FOR}

The $1 \frac{1 / 4}{4}$ percentage point rise in the revolving consumer credit portion of the financial obligations ratio over the past decade and half is almost as large as the rise in the total FOR over that period ${ }^{20}$ How much of the increase in the revolving credit FOR is attributable to the developments in the credit card market discussed above? One can estimate the contribution by comparing actual financial obligations with those associated with "counterfactual" scenarios in which the effect of changes in the credit card market are removed from the data. The following sections present a sounterlactual scenario for each of the three credit card market developments and one for all three together.

\section{The Effect of the Increase in Carlholding}

The effect of new cardholders on the revolving credit FOR can be estimated by calculating the ratio under the sounterlactual scenario in which the proportion of households holding at least one card remained at its

19. T)ata from the Fetheral Resertets Quarlerly Report of Cretit

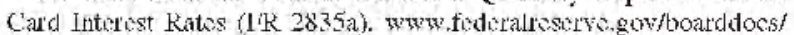
reportforms/ReporLT)elail.cfm (uncler "Cateyories of forms" select "Fusinessfoomsumer (redit") and author"s culculations.

20. The rewolving consunse credit portion of the l:OR-the livel of monthy payments on such ardit relative to disposable incomeis calculated from the level of reyolving credit balances. Payments on revolying credit balaness-the numstater of the rewlying credit liok - are assumed to be $2 / 2$ prenent of thase balances. This assumpLion correspomels to the avertige minimum recluired payment implied by respomses to the Federal Reserve System*s Tanuary ] d99 Senior Loan Ofticar Surwey on Bank Lending Practices. In that surwey, loan otticars also indicated that minimums had hot changed substantially over the previous tecade. Responsex to the 2003 Consumer Action surFey of banks also implicd an average minimum payment of botwesn 2 pursont and 3 porwent (Consimer Action News, "Anmual Crectil Card Survey $200 z^{\prime \prime}$.

More recently, some lenders haye thanced their patyment formula so that minimm payments squal curront fimance charges and tios plus some small amount of the oulstanting batance (Comsamer At fion News: "Annutal Cretit Card Survy 2005"). This new formula could raist or lower required payments. depending on the interest rate: and the amount of balane repaid. (1'or the Consumer Action We'ws surveys, see www.comsumer-acliom.org/F.nglish/library/credit_card.s/ inder.php.) 
1989 level. Using the statistical model described above, cardholders were divided into one group that probably acquired cards after 1989 , called new cardholders, and another group that probably had credit cards before 1989, called existing cardholders. The counterfactual revolving credit FOR was based on the debt of only the latter group, and the difference between the counterfactual and actual revolving credit FOR represents the effect of new cardholders.

New cardholders are defined as those households with the lowest probability of holding a credit card (see also table 2). For each triennial SCF from 1992 to 2001, enough new cardholders were removed from the group of cardholders to reduce the share of households with cards to its 1989 value. ${ }^{21}$ The growth in credit card debt associated with the households who acquired cards after 1989 accounted for about 9 percent of the growth in total credit card debt between 1989 and the second quarter of $2005 . .^{22}$

The counterfactual revolving credit FOR with the debt of the new cardholders removed is below the actual level (chart 4). The results imply that had the share of households with credit cards remained at its 1989 level, the rise in the FOR would have been about $1 / 3$ percentage point smaller than it actually was. A general substitution toward credit cards from other types of consumer loans and, more recently, away from credit cards toward mortgages also affected the amount of credit card debt, although the effect on overall household financial obligations is ambiguous (see box "Substitution between Credit Cards and Other Forms of Credit").

\section{The Effect of Variable Interest Rates}

The greater responsiveness of credit card interest rates to market rates, combined with a significant change in market rates in the early part of this decade, had a substantial effect on household financial obligations. The average real credit card interest rate fell more than 3 percentage points from the fourth quarter of 2001 to the second quarter of 2004, when it reached its low point, about $11 \frac{1 / 4}{4}$ percent. When credit card interest rates fall, households demand

21. About 31/a prosent of cartholders were removed in 1992, 6/\% porcent in 1995, 4\% present in 1998, and almost 9 porcent in 2001. To extend the amalysis through the second quarter of 2005, the share of crectit card debl held by new cardholders was kept constant at its 2001 valus.

22. This estimaled effect is slightly smaller than that calculated by Yoo (1997, 19198), who assumes that new cardholders have the same amount of debt as sxisting holders. Ilowswe. now cardhoders appoar to have a bit less dobt than existing holders; tor trample, in 2001. the ayeraye credil cart balance of a new cardholeler was ahoul \$2.180, whereas the averaye balance of al e xisting carcholder was $\$ 2,332$.
4. Effect on the revolving credit FOR of an increasing share of households that own credit cards, 1989-2005:Q2

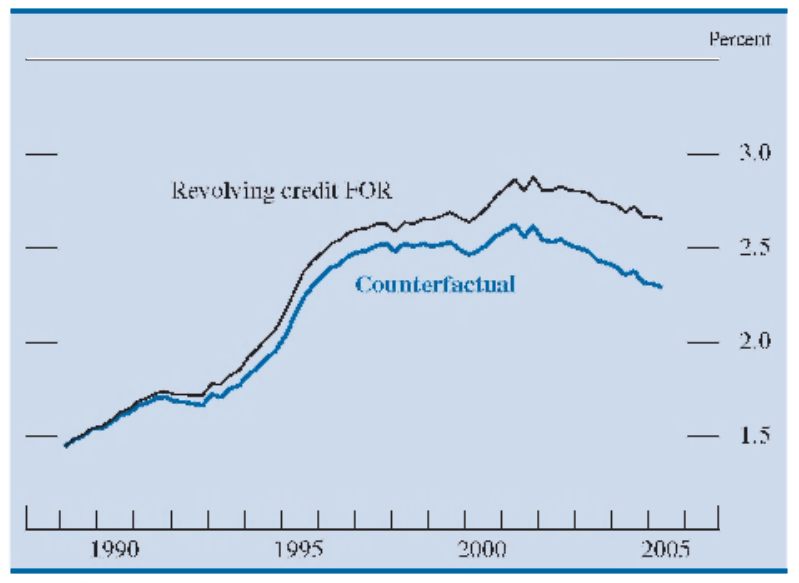

Note: The data are quarterly. The sounterfactua data consist of the consumer revolving credit FOR only for households that had a credit card in 1989. For details, see text; see also note to chart 2.

SOURCE: Federal Reserve Board and author's calculations.

significantly more credit card debt. For example, researchers have estimated that a 1 percent decline in interest rates on bank-issued credit cards leads to a $1 \frac{1}{3}$ percent rise in the demand for credit card debt 23

A decline in credit card interest rates that leads to a smaller margin over the cost of funds could also cause lenders to reduce their supply of credit card debt, which in turn could damp the amount of credit card debt outstanding. However, in the short run, the effect seems unlikely to be large because credit cards are open-ended credit contracts that specify only a credit limit. Most lenders are unwilling to reduce the credit line extended to existing customers in good standing. In a recent survey, 53 percent of banks reported reducing cardholder credit limits but usually only because the borrower had become riskier in some way. ${ }^{24}$ Hence, the responsiveness of demand to a change in rates would likely be the dominant determinant of the response of revolving debt outstanding to such a change.

To gauge the effect of changes in credit card interest rates on the revolving credit FOR, a counterfactual level of revolving credit was estimated under the assumption that interest rates on credit cards remained at their level in the first quarter of 1989. In particular, the change in real credit card debt predicted by the change in real credit card interest rates was subtracted from the actual level of debt.

23. Gross and Souletes $(2002)$. This effect was estimated without accounting for houstholds switching balances botwen cards as interest rates changs. Accounting for this switching reduces the rise in demand to aboul 1 percent.

24. Comsumer Ac'fiom News, "Annual Credil Card Survey 2005." 


\section{Substitution between Credit Cards and Other Forms of Credit}

Over the past fifteen years, households appear to have substituted some forms of credit for others. In the early part of this period, the rise in the share of household debt associated with credit card loans mirrored a decline in so-called "personal loans" and loans tied specifically to the purchase of durable goods other than vehicles. Trends in more recent years suggest that households may have been using mortgage loans as an alternative to credit card debt. The effect of this substitution on household financial obligations depends on the different terms associated with the different forms of debt.

Credit card loans have, in some respects, a significant advantage over personal loans (defined as unsecured, closed-end loans used to finance unspecified expenditures) as well as over the installment loans from department stores and finance companies that traditionally have been used to purchase large durable goods other than vehicles. In particular, the open-ended nature of credit card loans implies a lower fixed cost of borrowing: Households may draw on their credit card accounts to obtain needed funds (as long as borrowing remains below a pre-sel limit) as opposed to taking out an entirely new loan.

In deciding what form of credit to use, households weigh this cost advantage of credit cards against other traits of alternative loan types. One important feature is the interest rate. Because neither credit card loans nor personal loans are backed by collateral, interest rates are relatively high on both types of credit. All else equal, interest rates on installment loans backed by ronvehicle durable goods tend to be lower because they are secured. On balance, households appear to find the convenience of credit card loans to be appealing, as the ratio of jonwehick jonrevolvins loans to consumer loans dropped from 12 percent in 1989 to 6 percent in 2001.

The substitution of credit cards for other types of consumer loans may not have a large effect on the amount of consumer debt outstanding if households are simply replacing one form of credit for an equal amount of credit card debt. However, substitution can affect households' debtrelated financial obligations if the terms of credit card debt are different than the terms of the debt it replaced. For example, at current interest rates, the minimum required payment on a credit card loan would be 13 percent less than the payment on a personal loan of the same size. Even though the interest rates are similar, the credit card loan has a payment equivalent to a personal loan with a maturity almost one year longer than that of the typical personal loan.

In the past couple of years, households may have been substituting mortgage debt for credit card debt. For example, in 2004, outstanding mortgage debt increased about 14 percent while credit card loans grew only about 4 percent. Mortgage loans can be an attractive alternative to credit card borrowing because they have lower interest rates and because mortgage interest payments are tax deductible. Indeed, in surveys, households report using a significant share of the proceeds from cash-out mortgage refinancing transactions-which involve liquidating home equity by taking out a larger mortgage loan-to pay down credit card loans (Canner, Dynan, and Passmore, 2002).

All told, substitution toward first-lien mortgages tends to lower required payments on financial obligations because they have lower interest rates and longer maturities. However, substitution toward mortgage debt does not always reduce required debt payments; for example, the terms on home equity lines of credit (generally a junior lien) are usually similar to those on credit card debt. The transfer of consumer debt to mortgage debt may be limited by the higher costs of defaulting on a mortgage (which could involve loss of the home) and the fact that only homeowners have access to mortgage credit.
From 1989 to 2000 , the counterfactual revolving credit FOR follows the actual revolving credit FOR fairly closely (chart 5); this tracking is not surprising given that the real interest rate moved little over this period. Beginning in 2001, when the real credit card interest rate began to decline, the counterfactual revolving credit FOR began to lag the actual. By mid-2004, the counterfactual series was about $1 / 3$ percentage point below the actual. This gap implies that the decline in real credit card interest rates in the early part of this decade accounts for a material part of the rise in the revolving credit FOR between 1989 and the second quarter of $2005 .^{25}$

25. This analysis ignores the point that interest rales on mortyages fell as well over this period, a development that likely incluced

\section{The Effect of Transactions Demand}

As noted above, transactions-related credit card balances as a share of measured revolving debt rose from about 6 percent in 1992 to 11 percent in 2001. To estimate the effect of this increase in transactions demand on the revolving credit FOR, a counterfactual ratio was calculated under the assumption that the transactions demand for credit cards did not grow as a fraction of total revolving credit after 1989. In the second quarter of 2005, the counterfactual level of the revolving credit FOR was a little more than

houstholds to borrow mors against their homes and use the prockeds to pay down credit cad debt, which is more costly. Soe box "SubstiLulion between Chedil Cards and Other Forms of Crectil" For further discussion of this potential eflect. 
5. Effect on the revolving credit FOR of a falling real interest rate, 1989-2005:Q2

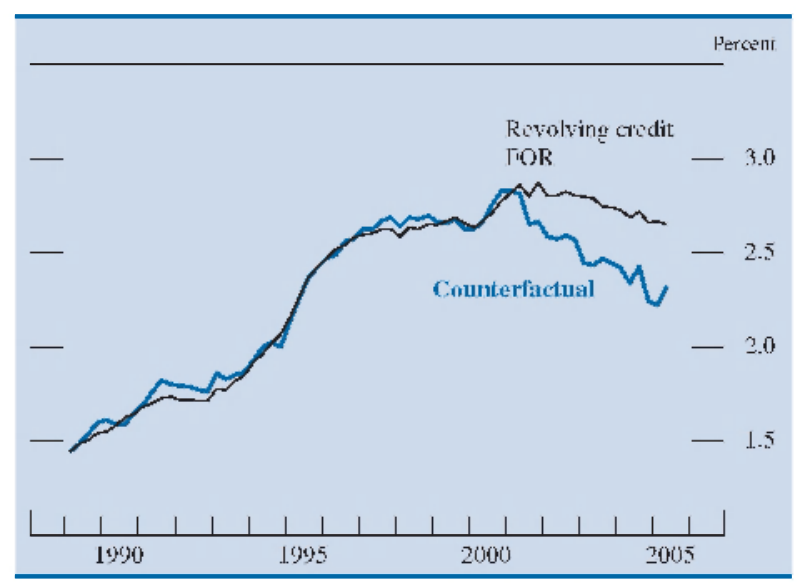

NotE: The data are quarterly. The sunlerliclua data consist of the consumer revolving credit FOR predicted if the average real credit card interest rate had remained at its 1989:Q1 level. For detalls, see text; see also note to chart 2.

SOURCE: Federal Reserve Board and author's calculations.

$1 / 3$ percentage point lower than the actual revolving credit FOR (chart 6); this gap represents the cumulative effect of the rise in transactions demand since 1989.

\section{The Combined Effect of the Three Credit Card Market Developments}

A simple combination of the estimated effects of the increase in the share of households that hold credit cards, the fall in real credit card interest rates, and the rise in transactions demand explains virtually all of

6. Effect on the revolving credit FOR of rising transactions-related use of credit cards, 1989-2005:Q2

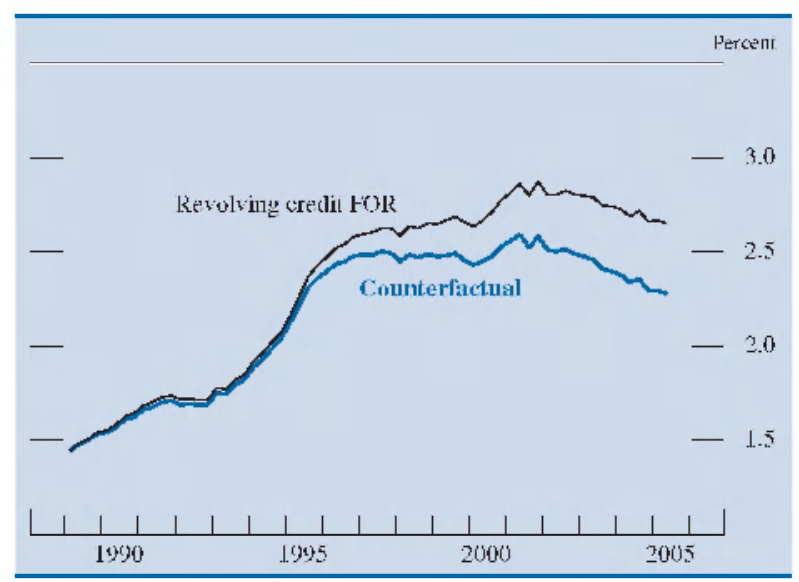

NoTE: The data are quarterly. The sounlerluclua data consist of the consumer revolving credit FOR predicted if the proportion of credit card debt arising from transactions-related use had remained at its 1989 level. For detalls, see text; see also note to chart 2 .

SOURCE: Federal Reserve Board and author's calculations. the net increase in the overall revolving credit FOR since 1989 (chart 7). However, these effects may not be entirely independent of one another; as a result, the sum of the three effects should be considered an upper bound. For example, a decline in the interest rate may cause an increase in debt partly because it may prompt households to apply for a first credit card; in this case, the sum of the influences captures the interest rate effect twice. Yet, the overlap may be limited by the fact that these effects, to some degree, pertain to different segments of the credit card market. For example, transactions demand has grown mainly among upper-income households that have held credit cards for a long time and are not sensitive to interest rates because they pay off their credit card balances each month.

The counterlactual revolving credit FOR rose significantly through 1997, but it has since reversed about all of the increase. This evolution raises a question about the determinants of revolving credit card debt apart from the three credit card developments analyzed above. One possible determinant is consumer confidence: The counterfactual revolving credit FOR seems to move broadly with consumer sentiment (chart 8; the vounterfactual FOR here is the same as shown in chart 7). The co-movement hints, perhaps, that when households become more confident, holding other market developments constant, they may choose to increase their revolving debt faster than their disposable personal income increases; conversely, when confidence declines, such revolving debt increases more slowly than does disposable personal income.

7. Combined effects on the revolving credit FOR of developments in the credit card market, 1989-2005:Q2

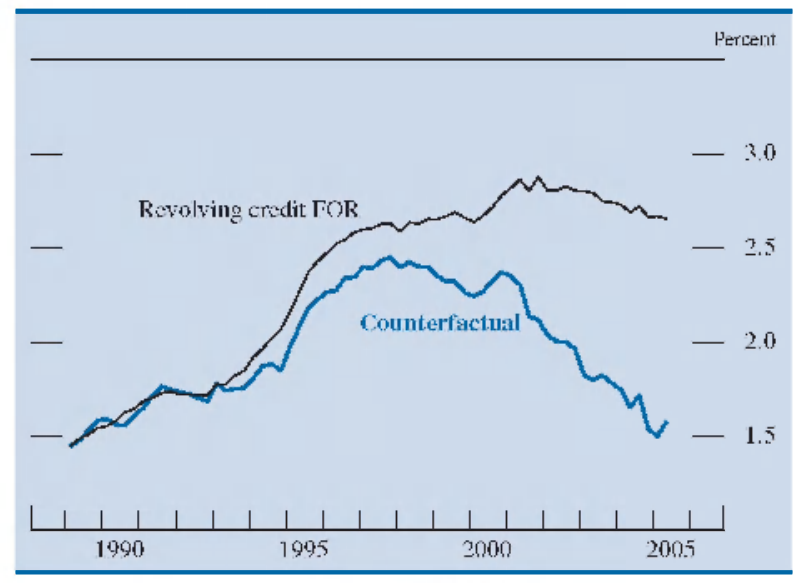

NOTE: The data are quarterly. The counterfactua data combine the effects of the developments shown in charts 4-6. For details, see text; see also note to chart 2 .

SOURCE: Federal Reserve Board and author's calculations. 
8. Counterlictua revolving credit FOR and consumer sentiment, 1989-2005:Q2

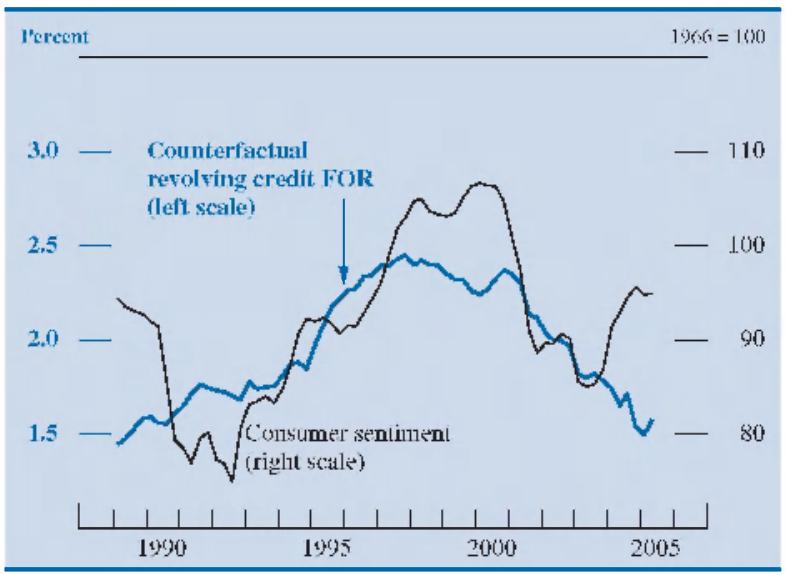

NoTE: The data are quarterly. For definition of the sounlerlikitua revolving credit FOR, see note to chart 7.

SOURCE: For vounlerlactua data, Federal Reserve Board and author's calculations; for consumer sentiment, the University of Michigan Survey Research Center.

\section{CONCLUSION}

Three developments in the credit card market contributed to the rise in the overall household FOR during the past fifteen years. Had the share of households with credit cards, the level of credit card interest rates, and the transactions-related demand for credit cards all remained at their 1989 levels, credit card debt outstanding in 2005 would have been significantly lower. In the absence of other changes, the rise in the total FOR over the past fifteen years would have been as much as 1 percentage point smaller than it actually was, a reduction that would have left the the 2005 FOR well in line with levels that existed earlier (chart 9).

The various sources of the rise in the revolving credit FOR have differing implications for the health of the household sector and the broader financial system. For example, the part of the rise stemming from a greater use of credit cards to pay for day-today purchases will not necessarily signal greater financial vulnerability among households if they are willing and able to pay off these card charges each month. As a related matter, the growth of transactions demand as a share of new borrowing may lessen the exposure of credit card issuers to defaults if households are more likely to pay off transaction balances than they are longer-term balances.

However, the implications of the rise in financial obligations associated with the decline in credit card interest rates in the early part of this decade are more complicated. A key issue would be the effect on households as interest rates rise. An increase in inter-
9. Household financial obligations ratio, 1980-2005:Q2

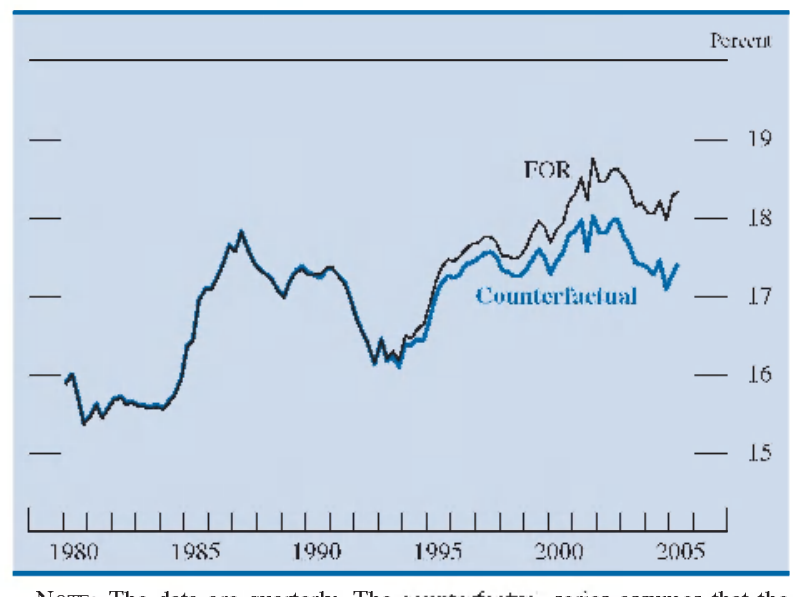

NotE: The data are quarterly. The sountirfactua series assumes that the level of revolving debt equals the level used to calculate the vounlerlictual revolving credit FOR. For details, see text; see also note to chart 7.

SOURCE: Federal Reserve Board and author's calculations.

est rates would likely damp demand for credit card debt and thus lead to a partial reversal of the rise in the revolving credit FOR. At the same time, rising rates could make it more difficult for some households to repay their existing debt.

Whether the rise in the share of households with a credit card is a cause for concern at the aggregate level depends on whether the benefits to the macroeconomy of the expansion of credit card availability outweigh the risks. New cardholders may be less adept at managing their credit than existing cardholders, and ready access to credit may make them more prone to taking on unmanageable levels of financial obligations. However, this ready access to credit may also help them maintain their consumption during temporary income distuptions, which could help smooth macroeconomic fluctuations. ${ }^{26}$

All told, an important implication of the analysis here is that researchers should exercise caution when comparing levels of the financial obligations ratio over long periods. Specifically, the factors behind an increase in the FOR should be identified and evaluated before one concludes that the increase implies greater financial fragility for the U.S. household sector or for the macrocconomy more broadly.

\section{REFERENCES}

Agarwal, Sumit, Souphala Chomsisengphet, Chunlin Liu, and Nicholas S. Souleles (2005). "How Well Do Consumers Forecast Their Future Borrowing?"

26. See Tyman, Flnendorf, ant Sichel (fortheoming). 
paper presented at the conference "Recent Developments in Consumer Credit and Payments," sponsored by the Federal Reserve Bank of Philadelphia, September 29-30.

Aizcorbe, Ana M., Arthur B. Kennickell, and Kevin B. Moore (2003). "Recent Changes in U.S. Family Finances: Evidence from the 1998 and 2001 Survey of Consumer Finances," Federal Reserve Bulletin, vol. 89 (January), pp. 1-32.

Ausubel, Lawrence M. (1991). "The Failure of Competition in the Credit Card Market," American Economic Review, vol. 81 (March), pp. 50-81.

Black, Sandra E., and Donald P. Morgan (1998). "Risk and the Democratization of Credit Cards," Research Paper 9815. New York: Federal Reserve Bank of New York, June.

Bostic, Raphael W. (2002). "Trends in Equal Access to Credit Products," in Thomas A. Durkin and Michael E. Staten, eds., The Impact of Public Policy on Consumer Credit. Boston: Kluwer, pp. 171203.

Brito, Dagobert L., and Peter R. Hartley (1995). "Consumer Rationality and Credit Cards," Journal of Political Economy, vol. 103 (April), pp. 400-33.

Calem, Paul S., Michael B. Gordy, and Loretta J. Mester (2005). "Switching Costs and Adverse Selection in the Market for Credit Cards: New Evidence." Working Paper 05-16. Philadelphia: Federal Reserve Bank of Philadelphia, July.

Calem, Paul S., and Loretta J. Mester (1995). "Consumer Behavior and the Stickiness of Credit-Card Interest Rates," American Economic Review, vol. 85 (December), pp. 1327-36.

Canner, Glenn, Karen Dynan, and Wayne Passmore (2002). "Mortgage Refinancing in 2001 and Early 2002," Federal Reserve Bulletin, vol. 99 (December), pp. 469-90.

Crook, Jonathan (2002). "Adverse Selection and Search in the Bank Credit Card Market." Credit Research Centre, Working Paper 01/2. Edinburgh: University of Edinburgh, www.crc.man.ed.ac.uk/ papers2002.html.

Duca, John V:, and William C. Whitesell (1995). "Credit Cards and Money Demand: A Cross-
Sectional Study," Journal of Money, Credit, and Banking, vol. 27 (May), pp. 604-23.

Dynan, Karen, Douglas W. Elmendorf, and Daniel E. Sichel (forthcoming). "Can Financial Innovation Help to Explain the Reduced Volatility of Economic Activity?" Journal of Monetary Economics.

Dynan, Karen, Kathleen Johnson, and Karen Pence (2003). "Recent Changes to a Measure of U.S. Household Debt Service," Federal Reserve Bulletin, vol. 89 (October), pp. 417-26.

Edelberg, Wendy (2003). "Risk-Based Pricing of Interest Rates in Household Loan Markets," Finance and Economics Discussion Series 200362. Washington: Board of Governors of the Federal Reserve System, December.

Evans, David S., and Richard Schmalensee (2005). Paying with Plastic: The Digital Revolution in Buying and Borrowing, 2nd ed. Cambridge, Mass.: MIT Press. 1st ed., 1999.

Gross, David B., and Nicholas S. Souleles (2002). "Do Liquidity Constraints and Interest Rates Matter for Consumer Behavior? Evidence from Credit Card Data," Quarterly Journal of Economics, vol. 117 (February), pp. 149-85.

Johnson, Kathleen W. (2004). "Convenience or Necessity? Understanding the Recent Rise in Credit Card Debt," Finance and Economics Discussion Series 2004-47. Washington: Board of Governors of the Federal Reserve System, September.

Klee, Elizabeth C. (2004). "Retail Payments 19952001: Findings from Aggregate Data and the Survey of Consumer Finances," unpublished paper. Board of Governors of the Federal Reserve System, Division of Monetary Affairs, May.

Mandell, Lewis (1972). Credit Card Use in the United States. Ann Arbor, Mich.: Institute for Social Research.

McCorkell, Peter L. (2002). "The Impact of Credit Scoring and Automated Underwriting on Credit Availability," in Thomas A. Durkin and Michael E. Staten, eds., The Impact of Public Policy on Consumer Credit. Boston: Kluwer, pp. 209-20.

Siedman, Ellen, Moez Hababou, and Jennifer Kramer 
(2005). "A Financial Services Survey of Low- and Moderate-Income Households," paper presented at the Federal Reserve System Community Affairs Research Conference "Promises and Pitfalls: As Consumer Finance Options Multiply, Who is Being Served and at What Cost?" Washington, D.C., April 7-8, www.chicagofed.org/cedric/ promises_pitfalls_2005_conference. cfm.

Stango, Victor (2000). "Competition and Pricing in the Credit Card Market," Review of Economics and Statistics, vol. 82 (August), pp. 499-508.

U.S. Department of Commerce (2005). "Quarterly Retail E-Commerce Sales: 2nd Quarter 2005," U.S. Census Bureau News, August 19.

White, Kenneth J. (1976). "The Effect of Bank Credit Cards on the Household Transactions Demand for Money," Journal of Money, Credit, and Banking, vol. 8 (February), pp. 51-61.
Yoo, Peter S. (1997). "Charging Up a Mountain of Debt: Accounting for the Growth of Credit Card Debt," Federal Reserve Bank of St. Louis, Review, vol. 79 (March-April), pp. 3-14.

(1998). "Still Charging: The Growth of Credit Card Debt between 1992 and 1995," Federal Reserve Bank of St. Louis, Review, vol. 80 (January-February), pp. 19-28.

Zinman, Jonathan (2005). "Debit or Credit?" unpublished paper, Dartmouth College, Department of Economics, October. 